\title{
Response of Cultivated Broccoli and Red Cabbage Crops to Mineral, Organic and Nano-fertilizers
}

\author{
Ahmed El-Henawy*, Islam El-Sheikh, Abdelhamid Hassan, Abdelsalam Madein, \\ Abdelazeem El-Sheikh, Abdalla El-Yamany, Aliaa Radwan, Fatema Mohamed, \\ Mohamed Khamees, Mahmoud Ramadan, Manar Abdelhamid, Hagar Khaled, \\ Heba El-Faramawy, Yahia Ayoub, Sarwat Youssef and Salah E.D. Faizy \\ Soil and Water Dept., Faculty of Agriculture, Kafrelsheikh University, Egypt.
}

$\mathbf{T}$ HE INTEGRATED application of different fertilizers including nano-fertilizers is a major area of interest within the modern agriculture. A field experiment was carried out aiming to investigate the effects of different types of fertilizers on growth development and productivity of red cabbage and broccoli under salinity and waterlogging stresses. The applied fertilizers included mineral fertilizer (i.e., recommended NPK fertilizers), organic fertilizer (i.e., compost tea) and nano-fertilizers (i.e., copper nanoparticles as nano- $\mathrm{Cu}$ ) and selenium nanoparticles as nano-Se). The results verified that the vegetative growth of red cabbage and broccoli may depend on the kind of fertilizer. The recent results showed that treatments of nano-Se, nano$\mathrm{Cu}$ and compost tea enhanced the plant growth, tolerance of plants to insects and induced the productivity. Our results revealed that integration of nano-fertilizers with organic fertilizers (compost tea) might be promising tool in modern and non-conventional agriculture. However, more investigations are still needed to clarify the effectiveness of these nanoparticles as well as the possible risks of using these nanomaterials if any.

Keywords: Copper nanoparticles, Selenium nanoparticles, Compost tea, Sustainable agriculture, Broccoli, Red cabbage.

\section{Introduction}

Agricultural sector faces nowadays great challenges in seeking for the sustainability. These challenges include the ability to provide safe and enough nutrition for the global population and at the same time the conserving or maintaining of the agroecosystem services (Alshaal and El-Ramady 2017; Agyin-Birikorang et al. 2018; Mupambwa and Mnkeni 2018). Therefore, several approaches have been adapted for conservation and management of biological diversity to sustain and increase crop productivity as well as to enhance agroecosystem services (Jarvis et al. 2013; Singh et al.2017). Despite mineral fertilizers are essential for crop production, excess application of mineral fertilizers has detrimental consequences not only on quality of yield but also on agroecosystems. In addition, overdoses of mineral fertilizers are kind of energy wasting and it reduces nutrient use efficiency (Kaushik and Djiwanti 2017). The mineral N-fertilizers may get lost in due to many environmental processes such as runoff, leaching, emissions and volatilization. In general, about $50-70 \%$ of the applied conventional chemical fertilizers get lost in the environment causing economic, agronomical, environmental concerns and health threats. Therefore, new alternatives should be used for eco-friendly, economic and organic or sustainable agriculture such as organic-, bio- and nano-fertilizers as well as slow or controlled release fertilizers (El-Ramady et al. 2018).

The new types of fertilizers based on nanotechnology are considered promising and non-traditional solution to upgrade the farming production worldwide. The common applications of nanotechnology in agriculture include nanofertilizers, nano-pesticides and nano-carriers (Belal and El-Ramady 2016). The advancement and development of engineered nanoparticles is an imperative stage in agricultural field in particular using the biological methods. Although

*Corresponding author e-mail: aelhenawy@yahoo.com

DOI: 10.21608/JENVBS.2019.6797.1046

(C)2018 National Information and Documentation Center (NIDOC) 
these nano-fertilizers are important for the future agriculture, there are many potential risks on the agroecosystems (Khan and Rizvi 2017; Yata et al. 2018; Xu et al. 2018). Indeed, several investigations are needed to explore the efficacy of commercially available engineered nanomaterials on soil microbes, the proper application methods of nanofertilizers and the future of nanofertilizer market sector (Sanivada et al. 2017). Several studies have been published concerning the role of fertilizers in mineral form or nano-form using essential or beneficial nutrients such as selenium (e.g., El-Ramady et al. 2015a, b, c, d, e, f; Domokos-Szabolcsy et al. 2017; Shalaby et al. 2017) and silicon (e.g., Alsaeedi et al. 2017a, b; Alsaeedi et al. 2018). Surprisingly, nano-fertilizers have not yet been systematically and comprehensively investigated. Concerning the effects of nano-fertilizers on agroecosystems, several investigations should be conducted to follow and monitor the fate, behavior and biosafety of these nano-fertilizers on the ecosystems including plants, soils, water, microbes, etc.

Using of mineral and organic fertilizers in crop production was fast becoming a key instrument in agriculture, whereas the using of nano-fertilizers still needs much effort to confirm. Mineral and organic fertilizers also are one of the most widely used groups of fertilizers and have been extensively used for food production. Therefore, the main subjects of this study were to (1) evaluate the response of cultivated broccoli and red cabbage crops to mineral, organic and nanofertilizers under salt-affected soil; (2) identify the use of nano-fertilizers whether safe and economic for the agricultural environment or not and (3) to what extent, mineral and organic fertilizers can be replaced by nano-fertilizers?

\section{Materials and Methods}

To study the effects of different applied fertilizers on cultivated broccoli and red cabbage crops, a field experiment was carried out at the experimental farm of Faculty of Kafrelsheikh, Kafrelsheikh University. Broccoli (Brassica oleracea var. italica) and red cabbage (Brassica oleracea var. capitata) were cultivated on January $1^{\text {st }} 2018$ in salt-affected soil. The cultivated crops received different types of fertilizers: a) mineral fertilizers (i.e., $70 \mathrm{~kg} \mathrm{~N}, 45 \mathrm{~kg}$ P2O5 and $50 \mathrm{~kg}$ $\mathrm{K} 2 \mathrm{O}$ per acre as recommended doses)b) organic fertilizer (i.e., compost tea) c) nano-fertilizer (i.e., selenium nanoparticles (nano-Se) and copper Env. Biodiv. Soil Security Vol. 2 (2018) nanoparticles (nano-Cu)). Organic fertilizer was supplied by the Department of Microbiology, Soils, Water and Environment Research Institute, Sakha. The complete randomized plots design was used to apply the following treatments for both vegetable crops:

1. Negative control (no fertilizers were added) (Control).

2. Recommended doses of NPK fertilizers (NPK-mineral control)

3. Nano-selenium at $100 \mathrm{ppm}$ concentration (Nano-Se)

4. Nano-copper at 100 ppm concentration (Nano-Cu)

5. Organic fertilizer (Compost Tea).

The soil used is characterized as salt-affected soil having electrical conductivity of $4.49 \mathrm{dS} \mathrm{m}^{-1}$ and $\mathrm{pH} 8.65$. The clay content is more than $53 \%$ and the depth of soil water table was below 80 $\mathrm{cm}$. Mineral, organic and nano-fertilizers were applied after about 75 days from transplanting of vegetable crops as foliar application. The applied amounts were repeated again after 4 weeks. Nano-Se and nano-Cu were biologically produced at Agricultural Microbiology Laboratory, Soil, Water and Environment Research Institute, Agricultural Research Center, Giza, Egypt. High resolution transmission electron microscope (HRTEM, Tecnai G20, FEI; The Netherland) was used for the determining particle size of nanomaterials. Size of nano-Se ranged between 100-300 nm; while nano- $\mathrm{Cu}$ ranged between 350-500 $\mathrm{nm}$.

Control soil samples were taken before starting the experiment. Chemical and physical properties of soils were assessed according to Page et al. (1982) and Klute (1986), respectively. The head weight of red cabbage and broccoli as well as some vegetative measurements including number of plants per plot and leaves per plant, stem length and diameter, leaf area, head weight and chlorophyll content were measured. Chlorophyll content and leaf area were measured at Horticulture Department, Faculty of Agriculture, Kafrelsheikh University. All vegetative parameters were recorded weekly.

\section{$\underline{\text { Results and Discussion }}$}

Vegetative parameters of red cabbage and broccoli after first foliar application of mineral, organic and nano-fertilizers, applied separately, are presented in Fig. 1. Although no big differences of number of red cabbage plants per plot were noticed among treatments, but treatments of nano- 
$\mathrm{Se}$, nano- $\mathrm{Cu}$ and compost tea had higher values. Treatments of NPK and nano-Se as well as control recorded nearby the same number of leaves per red cabbage plant; while nano- $\mathrm{Cu}$ and compost tea possessed the lowest counted number of leaves per plant. Interestingly, treating red cabbage plants by nano-Se, nano- $\mathrm{Cu}$ and compost tea resulted in the same head diameter but these values were lower than those measured for NPK-treated plants and control. Plant height was almost the same among all treatments including control; however, the lowest number was related to control.
Regarding broccoli plants after first application of treatments, number of plants per plot showed the highest value (4.0) at treatments of nanoSe and compost tea compared to control (3.5). The highest value (21) of number of leaves per broccoli plant was denoted to treatment of nanoSe, whilst the lowest recorded value (16) was seen for compost tea treatment. Similarly, nanoSe treatment resulted in the highest head diameter $(13 \mathrm{~cm})$ compared to $7.2 \mathrm{~cm}$ as lowest measured value for control plants. The plant height of nanoSe treated broccoli plants was the highest among all treatments, while control plants possessed the
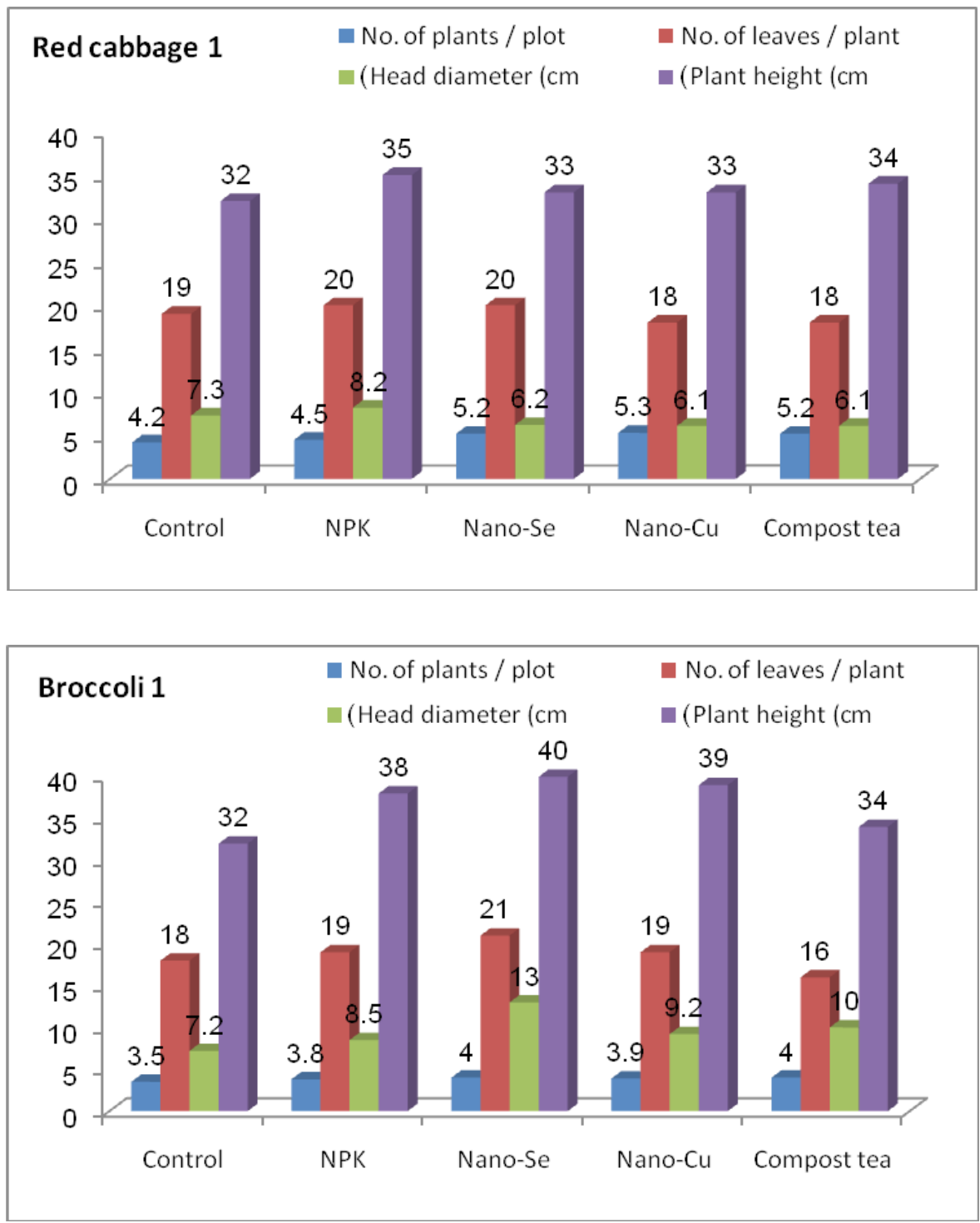

Fig. 1. Vegetative growth parameters of red cabbage and broccoli after the first foliar application of fertilizers. 
shortest height.

Vegetative parameters of red cabbage and broccoli after second foliar application of mineral, organic and nano-fertilizers, applied separately, are presented in Fig. 2. All treatments showed higher number of leaves or red cabbage compared to control; while head diameter of red cabbage was almost the same among all treatments. Control plants of red cabbage had the shortest plant height, but treated plants were taller regardless of treatment type. For broccoli plants, compost tea treatment had the lowest number of leaves (13), while control plant had the highest number of leaves (19). Head diameter of broccoli was the highest for plants treated by nano- $\mathrm{Cu}$;
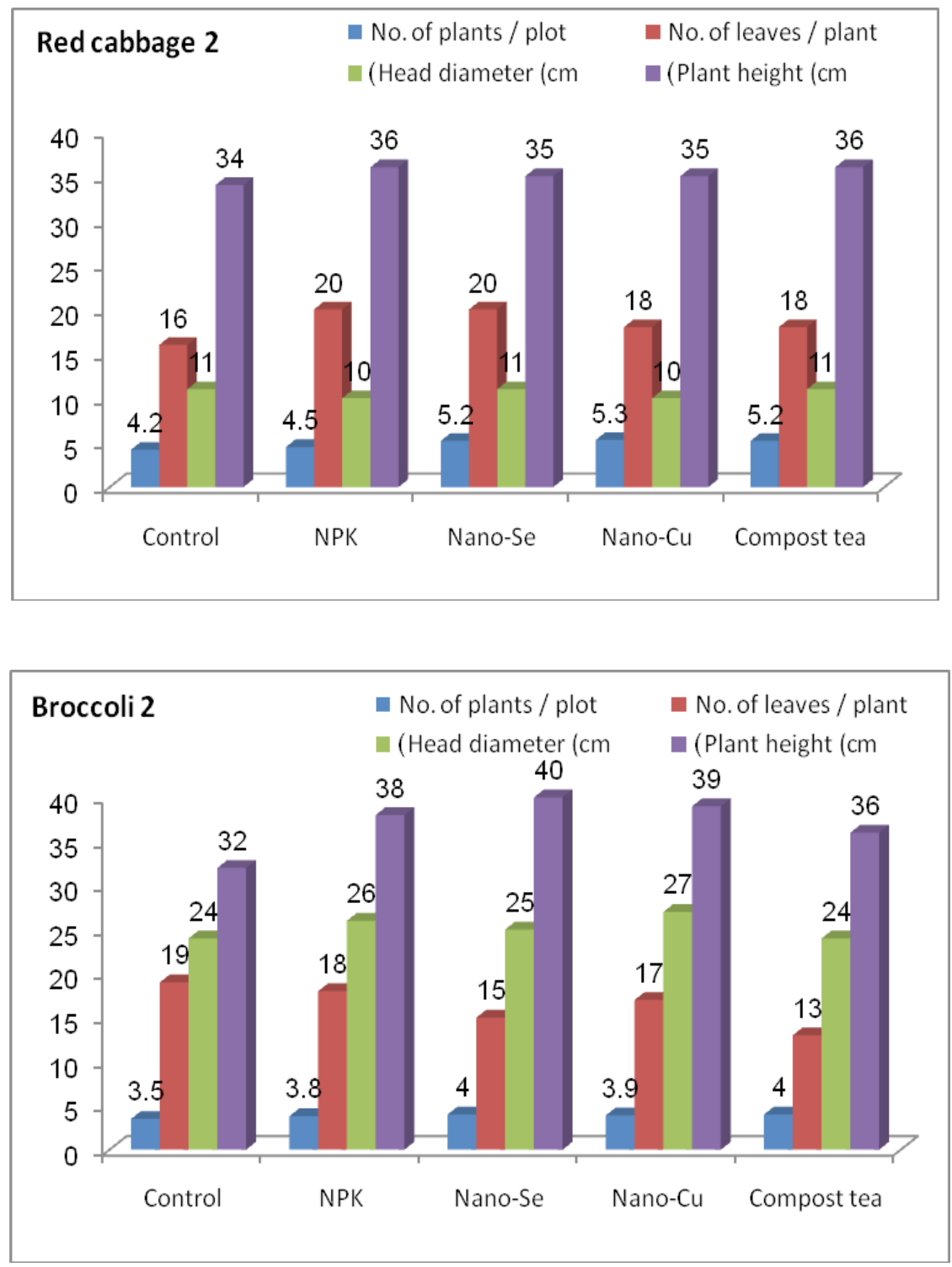

Fig. 2. Vegetative growth parameters of red cabbage and broccoli after the second foliar application of fertilizers.

whilst compost tea treatment and control had the lowest head diameter.

Data in Fig. 3 present chlorophyll content (SPAD), leaf area, infection rate and head weight of red cabbage and broccoli plants after treating by NPK, nano-Se, Nano-Cu and compost tea. Results showed that nano- $\mathrm{Cu}$ had the greatest Env. Biodiv. Soil Security Vol. 2 (2018) influence on chl content among all treatments for red cabbage plant recording the highest chl content (160); while broccoli plants had the highest chl content when they were treated by compost tea (118). Largest leaf area of red cabbage $\left(454 \mathrm{~cm}^{2}\right)$ and broccoli $\left(250 \mathrm{~cm}^{2}\right)$ was linked to compost tea and nano-Se treatments, respectively. Red 
cabbage plants had the lowest infection rate by insects when they were treated by nano-Se. On the other hand, nano-Cu treatment resulted in the lowest infection rate of broccoli plants. Compost tea treatment resulted in the highest head weight of both red cabbage and broccoli plants. These results revealed that the integrated management is the best way for ensuring the sustainability. For example, compost tea treatment resulted in the highest biomass but in the same time plants were more susceptible for insect; therefore treating plants by both compost tea and nano-Se and nano$\mathrm{Cu}$ would achieve the highest productivity and in the same time the greatest tolerance to insects (Fig. 4 and 5). This experiment was an attempt to evaluate: (1) The single effect of different kind of fertilizer on productivity of these vegetable crops under salt-affected soils; (2) Make a comparison between the conventional and nano-fertilizers;
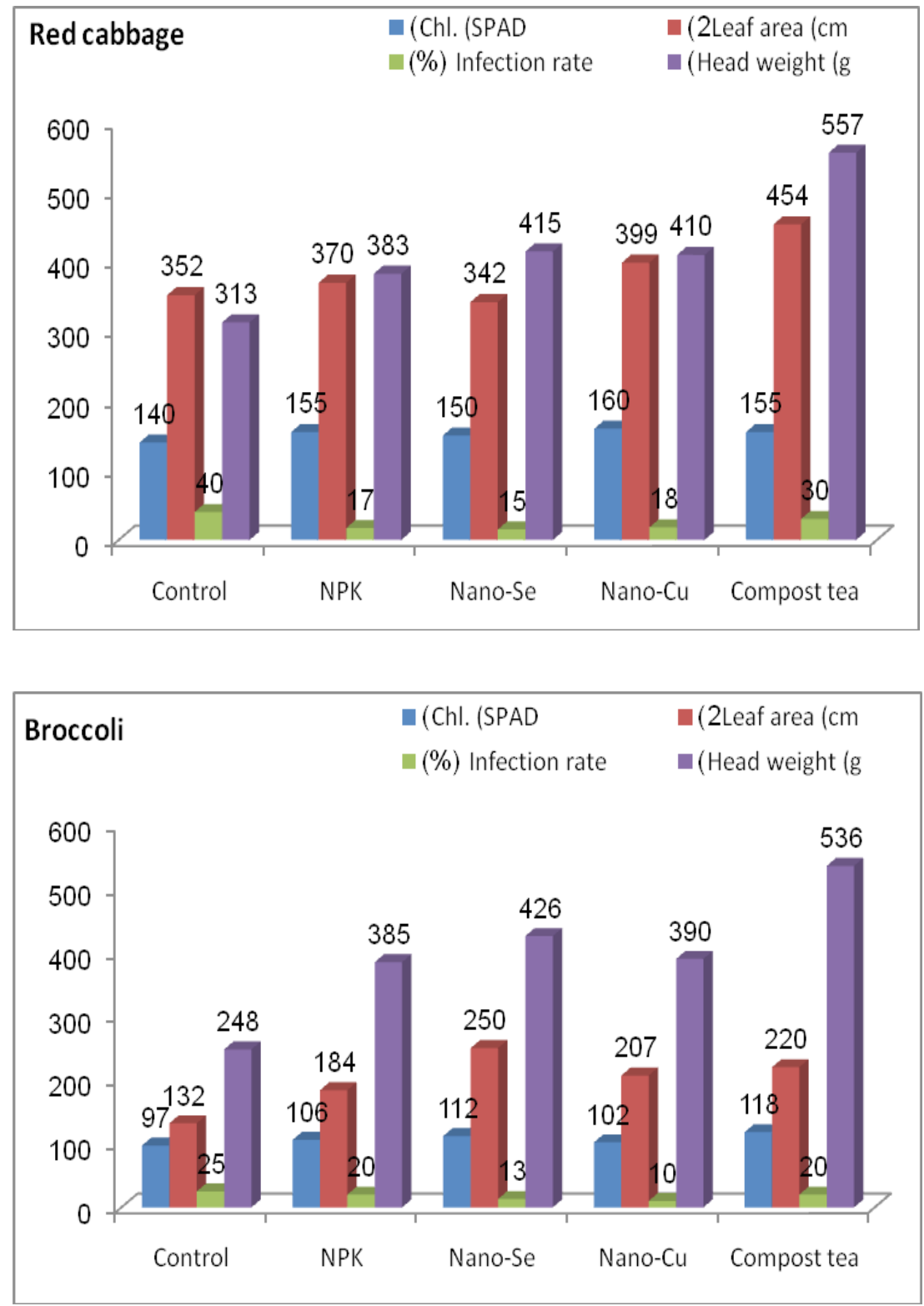

Fig. 3. Response of vegetative growth parameters of red cabbage and broccoli, head weight and infection rate to foliar application of fertilizers at harvest. 

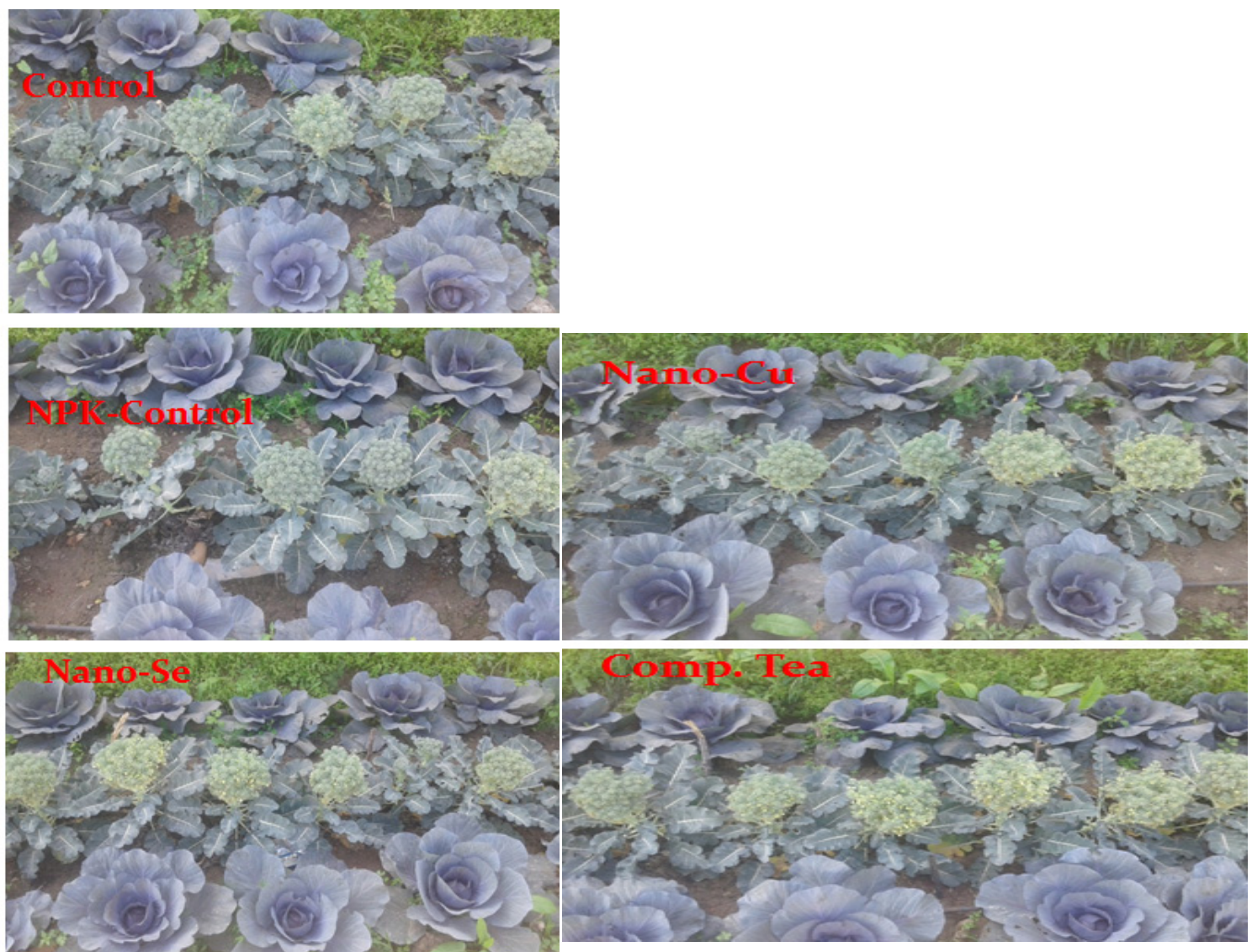

Fig. 4. An overview of the cultivated vegetable plants in the field after 2 weeks from foliar fertilizers application.
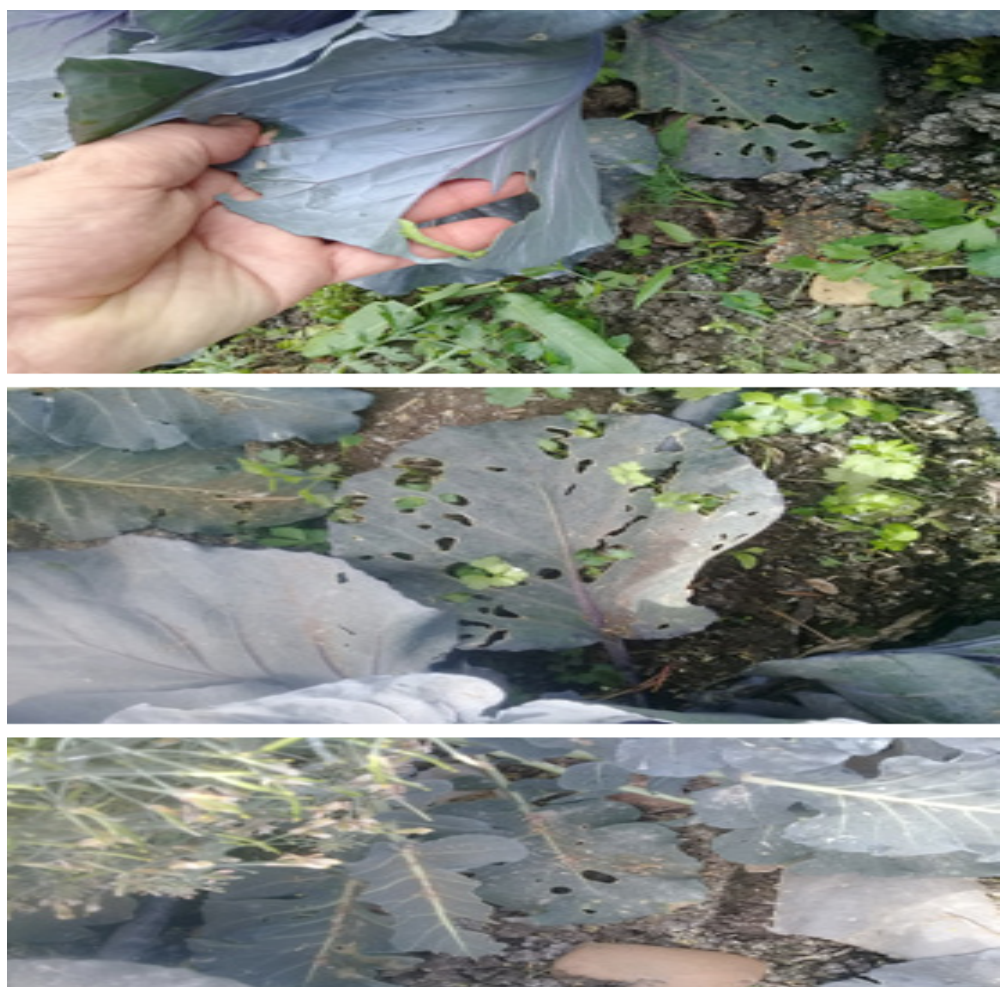

Fig. 5. An overview of some infected cultivated vegetable plants in the field after the application of foliar fertilizers.

Env. Biodiv. Soil Security Vol. 2 (2018) 
and (3) Influence of different kind of fertilizers on plant resistance against pathogenic or infection.

Many remarks could be noticed from these results including: (1) Mineral fertilizers were and still one of the most important strategies in seeking for a high and enough yield from cultivated crops; (2) Organic fertilizer (i.e. compost tea) is NOT enough alone if we need to get the maximum production; (3) Nano-fertilizers need more investigations regarding their effects on soil biology, biofortified effects on human health, toxic effects on agroecosystem, etc.; (4) The biological method for preparing nano-fertilizers is the best and safe approach concerning the ecotoxicological effects on the environment; and (5) The integrated fertilization was and still one of the most important approaches in the sustainable agriculture.

\section{Integrated Soil Fertility Management (ISFM)}

It could be defined Integrated Soil Fertility Management (ISFM) as "A set of soil fertility management practices that necessarily include the use of fertilizer, organic inputs and improved germplasm combined with the knowledge on how to adapt these practices to local conditions in aim of maximizing the agronomic use efficiency of the applied nutrients and improving crop productivity". Any of the interventions is required to increase the efficiency and profitability of food production as related to use of land, labor, fertilizer inputs and financial investments. Integrated Soil Fertility Management combines agronomic practices relating to crops, mineral fertilizers, organic inputs and other amendments that are tailored for different cropping systems, soil fertility status and socioeconomic profiles. The first entry point of ISFM is focusing on the agronomy of crops and inorganic fertilizers. Interventions on germplasm involve the selection of varieties, spacing and planting date. Interventions on fertilizer use respectively target the formulation, placement, rate and timing of inorganic nutrient inputs. The second entry point of ISFM targets interventions on organic resource management, including the return of crop residues, manure, compost and other types of organic wastes, next to rotation or intercropping with legumes and use of plant growth promoting micro-organisms. The third and last entry point of ISFM deals with any other amendments that may be needed to lift limitations to productivity such as soil acidity, micronutrient deficiency, erosion, soil compaction or pests and diseases (Bationo et al. 2018).

Therefore, the soil fertility is an important component in the sustainability of agriculture. This component should follow all management practices to protect, conserve and sustain it through a vital program. This program should include all kinds of fertilizers in harmony such as mineral, organic, biological and nano-fertilizers. More investigations are needed concerning nano-fertilizers and their effects on different compartments of the agroecosystem.

\section{Evaluation of applied fertilizers}

It is thought that, mineral fertilizers cannot dispense them but should reduce the global amount of these fertilizers to protect and conserve our environment. The using of mineral, organic and biological fertilizers should be managed to conserve the soil fertility and to get the maximum crop production. It is well known that, organic manure is a commendable organic fertilizer, as it contains nitrogen, phosphorus, potassium and other essential nutrients. The most important factors responsible for low yield are inappropriate crop nutrition management and poor soil fertility. The field experiment was performed to evaluate the impact of different fertilizer (organic and inorganic) on yield and yield components of some vegetable crops.

Day by day, a lot of fertilizers could find in the market. Some of these fertilizers are already investigated and accepted by the agricultural society. But some of these fertilizes (in particular nano-fertilizers) are still just patents and definitely need more and more studies and evaluation. The most important point is to produce nano-fertilizers through the biological methods, which more safer and active comparing with physical and chemical methods. So, it could be recommended that the "biological" nano-fertilizers are considered a promising tool in agricultural production. Furthermore, it should use mineral, organic, biological and nano-fertilizers in harmony without unfair use or over-use of anyone. Therefore, it is not important to investigate and evaluate different kinds of fertilizers but also calculate the economic evaluation. Then, a recommendation can be posted to help farmers or stalk holders in their production. Further studies about the ecotoxicological effects of different fertilizers on agroecosystem are needed.

\section{Conclusion}

Concerning nano-fertilizers, nano- copper (nano- $\mathrm{Cu}$ ) and nano-selenium (nano-Se) have been used in this study. These nano-fertilizers

Env. Biodiv. Soil Security Vol. 2 (2018) 
were used in this investigation because of their role in enhancing the growth cultivated plants under both salinity and waterlogging stress. The effects of mineral and organic fertilizers on the crop productivity have been also discussed. The separate effects of these previous fertilizers (i.e. mineral, organic and biological nano-fertilizers) have been investigated. Further studies are needed to focus on the integrated application of these fertilizers. Therefore, soil fertility was and still and will be one of the most important strategies in the sustainable agriculture. This needs a comprehensive and an integrated program of fertilization. These fertilizers should include all kinds and should apply in right time, amount or dose, place and form as known with $4 \mathrm{R}$ strategy. Biological nano-fertilizers might be promising tools in modern and non-conventional agriculture. Furthermore, urgent investigations are needed to highlight on the risks of these nanomaterials if any.Therefore, it should apply the right amounts of nutrients for cultivated crops in the right time, place, and form to get the optimal crop production. The applied fertilizers also should be integrated (i.e., mineral or chemical, organic, bio- and nanofertilizers).

\section{Acknowledgements}

Authors acknowledge Dr. Hassan El-Ramady for his co-supervision on the students of the $4^{\text {th }}$ year during their graduation project, Soil and Water Dept., and his encouragement. Authors also thank both Dr. Tamer Elsakhawy and Dr. Alaa El-DeinOmara for their supplying Nano-Se and nano-Cu (Agricultural Microbiology Lab., Soil, Water and Environment Research Institute, Agricultural Research Center, Giza, Egypt). Deep thanks for Horticulture Dept., for their help in measuring chlorophyll content and leaf area.

\section{References}

Agyin-Birikorang A., J.H. Winings, X. Yin, U. Singh, J Sanabria (2018) Field evaluation of agronomic effectiveness of multi-nutrient fertilizer briquettes for upland crop production.Nutr. Cycl. Agroecosyst 110: 395-406. https://doi.org/10.1007/s10705-0189905-y

Alsaeedi A., H. El-Ramady, T. Alshaal, M. ElGarawani, Nevien Elhawat, A. Al-Otaibi (2018) Exogenous nanosilica improves germination and growth of cucumber by maintaining $\mathrm{K}^{+} / \mathrm{Na}^{+}$ ratio under elevated $\mathrm{Na}^{+}$stress. Plant Physiology and Biochemistry, 125:164-171.https://doi. org/10.1016/j.plaphy.2018.02.006
Alsaeedi A., T. A. Alshaal, H. El-Ramady and M. Almohsen (2017a) Enhancing seed germination and seedlings development of common bean (Phaseolus vulgaris) by $\mathrm{SiO}_{2}$ nanoparticles. Egypt. J. Soil Sci. 57 (4): 407 - 415. DOI: 10.21608/ EJSS.2017.891.1098

Alsaeedi A.H., H El-Ramady, T. Alshaal, M. ElGarawani, N. Elhawat, M. Almohsen (2017b) Engineered silica nanoparticles alleviate the detrimental effects of $\mathrm{Na}^{+}$stress on germination and growth of common bean (Phaseolus vulgaris). Environ Sci Pollut Res, 24 (27): 21917-21928. DOI 10.1007/s11356-017-9847-y

Alshaal T. and H. El-Ramady (2017). Sustainable agriculture: towards holistic overview. J. Sus. Agric. Sci. 43 (2): 65- 67. DOI: 10.21608/ JSAS.2017.1007.1002

Bansiwal A.K., Rayalu S.S., Labhasetwar N.K., Juwarkar AA, Devotta S (2006) Surfactantmodified zeolite as a slow release fertilizer for phosphorus. J Agric Food Chem 54, 4773-4779.

Barker A.V., Pilbeam D.J. (2015) Handbook of Plant Nutrition, Books in soils, plants, and the environment series, $2^{\text {nd }}$ edn. CRC Press, Boca Raton

Bationo A., J.O. Fening, A. Kwaw (2018) Assessment of Soil Fertility Status and Integrated Soil Fertility Management in Ghana. In: A. Bationo et al. (eds.), Improving the Profitability, Sustainability and Efficiency of Nutrients through Site Specific Fertilizer Recommendations in West Africa AgroEcosystems, DOI 10.1007/978-3-319-58789-9_7, Springer International Publishing AG

Belal E., H. El-Ramady (2016) Nanoparticles in Water, Soils and Agriculture. In: S. Ranjan et al. (eds.), Nanoscience in Food and Agriculture 2, Sustainable Agriculture Reviews 21, DOI 10.1007/978-3-31939306-3_10, Springer International Publishing Switzerland

Bortolin A., Aouada F.A., Mattoso L.H.C., Ribeiro C. (2013) NanocompositePAAm/methyl cellulose/ montmorillonite hydrogel: evidence of synergistic effects for the slow release of fertilizers. $J$ Agric Food Chem 6, 7431-7439.

Chebotarev N.T., A.A. Yudin, P.I. Konkin, AV Oblizov (2017) Efficiency of Using Organic and Mineral Fertilizers in Fodder Crop Rotation on Northern Soddy Podzols. Russian Agricultural Sciences, 43 (2), 162-166.

Chen H., Seiber J.N., Hotze M. (2014) ACS select on nanotechnology in food and agriculture: a perspective on implications and applications. $J$. Agri. Food. Chem. 62: 1209-1212.

Chhipa H. (2017) Nanofertilizers and nanopesticides for agriculture. Environ Chem Lett 15:15-22. DOI: 


\section{$10.1007 / \mathrm{s} 10311-016-0600-4$}

Compaore E., P. Cattan, J-BS Taonda (2011) Effect of Continuous Mineral and Organic Fertilizer Inputs and Plowing on Groundnut Yield and Soil Fertility in a Groundnut-Sorghum Rotation in Central Burkina Faso. In: A. Bationo et al. (eds.), Innovations as Key to the Green Revolution in Africa. DOI 10.1007/978-90-481-2543-2_61,Springer Science + Business Media B.V.

Ditta A., Arshad M., Ibrahim M. (2015) Nanoparticles in sustainable agricultural crop production: applications and perspectives. In: Siddiqui $\mathrm{MH}$ et al (eds.) Nanotechnology and Plant Sciences. Springer, Cham, pp 55-75. https://doi. org/10.1007/978-3-319-14502-0_4

Domokos-Szabolcsy É., T. Alshaal, N. Elhawat, N. Abdalla, A.R dos Reis, H. El-Ramady (2017) The Interactions between Selenium, Nutrients and Heavy Metals in Higher Plants under Abiotic Stresses. Env. Biodiv. Soil Security 1: 5 - 31. DOI: 10.21608/jenvbs.2017.951.1001.

El-Ramady H., Abdalla N., Alshaal T., DomokosSzabolcsy E., Elhawat N., Prokisch J., Sztrik A., Fa'ri M., El-Marsafawy S., Shams M.S. (2015c) Selenium in soils under climate change, implication for human health. Environ. Chem. Lett. 13(1): 1-19. doi:10.1007/ s10311-014-0480-4.

El-Ramady H., Abdalla N., Alshaal T., El-Henawy A., Faizy SE-DA, Shams M.S., Shalaby T., Bayoumi Y., Elhawat N., Shehata S., Sztrik A., Prokisch J., Fa'ri M., Pilon-Smits E.A., Domokos-Szabolcsy E. (2015a) Selenium and its role in higher plants. In: Lichtfouse E et al (eds.) Environmental Chemistry for A Sustainable World, vol 7. Springer Science + Business Media B.V., Dordrecht, pp 235-296. doi:10.1007/978-3-319-19276-5_6.

El-Ramady H., Abdalla N., Alshaal T., Elhenawy A.S., Shams M.S., Faizy SE-DA, Belal E.B., Shehata S.A., Ragab M.I., Amer M.M., Fari M., Sztrik A., Prokisch J., Selmar D., Schnug E., PilonSmits E.A.H., El- Marsafawy S.M., DomokosSzabolcsy E. (2015d) Giant reed for selenium phytoremediation under changing climate. Environ Chem. Lett. doi:10.1007/s10311-015-0523-5

El-Ramady H., Abdalla N., Alshaal T., Fari M., Prokisch J., Pilon-Smits E.A.H., Domokos-Szabolcsy E. (2015e) Selenium phytoremediation by giant reed. In: Lichtfouse Eric, Schwarzbauer Jan, Robert Didier (eds.) Environmental Chemistry for $A$ Sustainable World, vol. 6, Hydrogen production and remediation of carbon and Pollutants Springer Science ? Business Media B.V., Dordrecht, pp 133198. doi:10.1007/978-3-319-19375-5_4

El-Ramady H., Abdalla N., Fari M., DomokosSzabolcsy E. (2014d) Selenium enriched vegetables as biofortification alternative for alleviating micronutrient malnutrition. Int J Hortic. Sci. 20(12): 75-81. ISSN 1585-0404

El-Ramady H., Alshaal T., Abdalla N, Prokisch J, Sztrik A., Fari M., Domokos-Szabolcsy E (2015f) Selenium and nano-selenium biofortified sprouts using micro-farm system. In: The $4^{\text {Th }}$ International Conference of The International Society for Selenium Research (Issr) On "Selenium in The Environment and Human Health", 18-21 October 2015, Sao Paulo, Brazil.

El-Ramady H., Alshaal T., Amer M., DomokosSzabolcsy E., Elhawat N., Prokisch J., Fari M. (2014a). Soil quality and plant nutrition. In: Lichtfouse E (ed.) Sustainable Agriculture Reviews, Vol. 14, Springer International Publishing, Switzerland, pp 345-447. doi:10.1007/978-3-31906016-3_11.

El-Ramady H., Alshaal T, Shehata S.A., DomokosSzabolcsy E., Elhawat N.., Prokisch J., Fari M., Marton L. (2014b) Plant nutrition: from liquid medium to micro-farm. In: Lichtfouse E (ed.) Sustainable Agriculture Reviews, Vol. 14. Springer International Publishing, Switzerland, pp 449-508. doi:10.1007/978-3-319-06016-3 12.

El-Ramady H., Domokos-Szabolcsy E., Abdalla N.A., Alshaal T.A., Shalaby T.A., Sztrik A, Prokisch J., Fari M. (2014c) Selenium and nano-selenium in agroecosystems. Environ Chem. Lett. 12(4): 495510. doi:10.1007/s10311-014-0476-0

El-Ramady H., Domokos-Szabolcsy E., Shalaby T.A., Prokisch J., Fari M. (2015b) Selenium in agriculture: water, air, soil, plants, food, animals and nanoselenium. In: Lichtfouse E (ed.) Environmental Chemistry For A Sustainable World, Vol. 5, $\mathrm{CO}_{2}$ sequestration, biofuels and depollution Springer, Berlin, pp 153-232. doi:10. 1007/978-3319-11906-9_5

El-Ramady H., N. Abdalla, T. Alshaal, A. El-Henawy, M. Elmahrouk, Y. Bayoumi, T. Shalaby, M. Amer, S. Shehata, M. Fari, E. Domokos-Szabolcsy, A. Sztrik, J. Prokisch, E.A.H. Pilon-Smits, M. Pilon, D. Selmar, S. Haneklaus, E. Schnug (2018) Plant Nano-nutrition: Perspectives and Challenges. In: KM Gothandam et al. (eds.), Nanotechnology, Food Security and Water Treatment, Environmental Chemistry for a Sustainable World 11, https:// doi.org/10.1007/978-3-319-70166-0_4, Springer International Publishing AG

Engelmann W., Leal D.W.S., Von Hohendorff R. (2017) The nanotechnological revolution and the complexity of waste: the possibility of using the OECD protocol as an alternative to nanowastes risk management. Adv.Recycl. Waste Manag. 2: 136. https://doi.org/10.4172/2475-7675.1000136

Env. Biodiv. Soil Security Vol. 2 (2018) 
Epstein E., Bloom A.J. (2005) Mineral Nutrition of Plants: Principles and Perspectives, 2nd edn. Sinauer, Sunderland

Fageria N.K. (2016) The Use of Nutrients in Crop Plants. CRC, Boca Raton

Fageria N.K., Baligar V.C., Jones C.A. (2011) Growth and Mineral Nutrition of Field Crops. The $3^{\text {rd }}$ ed., Books in soils, plants, and the environment series CRC Press, Boca Raton

Hartmann N.B., L.M. Skjolding, S.F. Hansen, J. Kjolholt, F. Gottschalk, A. Baun (2014). Environmental Fate and Behavior of Nanomaterials: New Knowledge on Important Transformation Processes. Danish Environmental Protection Agency, Copenhagen, Denmark

Iavicoli I., Leso V., Beezhold D.H., Shvedova A.A. (2017) Nanotechnology in agriculture: opportunities, toxicological implications, and occupational risks. Toxicol. Appl. Pharmacol 329: 96-111. https://doi.org/10.1016/j.taap.2017.05.025

Jarvis D.I., E. Khaka, P.L. Pert, L. Thiombiano, E. Boelee (2013) Managing Agroecosystem Services. In: E. Boelee (ed.), Managing Water and Agroecosystems for Food Security, CAB International

Jones Jr. J.B. (2012) Plant Nutrition And Soil Fertility Manual. The $2^{\text {nd }}$ Edition. CRC Press, Taylor \& Francis Group, LLC

Kannan S. (2010) Foliar Fertilization for Sustainable Crop Production. In: E. Lichtfouse (ed.), Genetic Engineering, Biofertilisation, Soil Quality and Organic Farming, Sustainable Agriculture Reviews 4, DOI 10.1007/978-90-481-8741-6_13, Springer Science + Business Media B.V.

Karimi E., E.M. Fard (2017) Nanomaterial Effects on Soil Microorganisms. In: M. Ghorbanpour et al. (eds.), Nanoscience and Plant-Soil Systems, Soil Biology 48, DOI: 10.1007/978-3-319-46835-8_5, Springer International Publishing AG

Kaushik S., S.R. Djiwanti (2017) Nanotechnology for Enhancing Crop Productivity. In: R. Prasad et al. (eds.), Nanotechnology, DOI 10.1007/978-981-104573-8_11, Springer Nature Singapore Pte Ltd.

Khan M.R., T.F. Rizvi (2017) Application of Nanofertilizer and Nanopesticides for Improvements in Crop Production and Protection. In: M. Ghorbanpour et al. (eds.), Nanoscience and Plant-Soil Systems, Soil Biology 48, DOI 10.1007/978-3-319-46835-8_15, Springer International Publishing AG

Klute A. (1986) Part 1.Physical and mineralogical methods. In Part 1.Physical and Mineralogical Methods, ed. $2^{\text {nd }}$ Ed. ASA-SSSA-Agronomy, Madison, Wisconsin USA.

Env. Biodiv. Soil Security Vol. 2 (2018)
Komarneni S. (2010) Potential of nanotechnology in environmental soil science. In: Proc. The $9^{\text {Th }}$ International Conference of The East and Southeast Asia Federation of Soil Science Societies, pp 16-20

Kottegoda N., Munaweera I., Madusanka N., Karunaratne V. (2011) A green, slow-release fertilizer composition based on urea-modified hydroxyapatite nanoparticles encapsulated wood. Curr. Sci 101: 1-7.

Li Z. (2003) Use of surfactant-modified zeolite as fertilizer carriers to control nitrate release. MicroporMesopor Mater 61: 181-188.

Liu X., Zhao-bin F., Fu-dao Z., Shu-qing Z., XU-sheng H.E. (2006) Preparation and testing of cementing and coating nano-subnanocomposites of slow/ controlled-release fertilizer. Agric. Sci. India 5: 700-706.

Manikandan A., Subramanian K.S. (2014) Fabrication and characterisation of nanoporous zeolite based $\mathrm{N}$ fertilizer. Afr J Agric Res 9: 276-284.

Matraszek R., Hawrylak-Nowak B., Chwil S., Chwil M. (2016) Macroelemental composition of cadmium stressed lettuce plants grown under conditions of intensive sulphur nutrition. J Environ Manag 180: 24-34

Mohanraj J. (2013) Effect of nano-zeolite on nitrogen dynamics and greenhouse gas emission in rice soil eco system. M. Tech. (Ag.) Thesis, TNAU, Coimbatore, India

Mupambwa H.A., P.N.S. Mnkeni (2018) Optimizing the vermicomposting of organic wastes amended with inorganic materials for production of nutrient-rich organic fertilizers: a review. Environmental Science and Pollution Research, https://doi.org/10.1007/ s11356-018-1328-4

Pachapur V.L., Larios A.D., Cledo'n M., Brar S.K., Verma M., Surampalli R.Y. (2016) Behavior and characterization of titanium dioxide and silver nanoparticles in soils.Sci Total Environ. 563-564: 933-943

Page A.L., R.H. Miller and D.R. Keeney (1982) Methods of Soil Analysis. Part 2. Soil Soc. Amer. Inc. Madison, Wisconsin, U.S.A.

Prasad R., Kumar V., Prasad K.S. (2014) Nanotechnology in sustainable agriculture: present concerns and future aspects. Afr J Biotechnol. 13: $705-713$

Purohit R., Mittal A., Dalela S. et al (2017) Social, environmental and ethical impacts of nanotechnology. Mater Today Proc (4): 54615467. https://doi.org/10.1016/j.matpr.2017.05.058

Reddy P.V.L., Hernandez-Viezcas J.A., Peralta-Videa J.R., Gardea-Torresdey J.L. (2016) Lessons 
learned: are engineered nanomaterials toxic to terrestrial plants? Sci Total Environ 568: 470-479

Sanivada S.K., V.S. Pandurangi, M.M. Challa (2017) Nanofertilizers for Sustainable Soil Management. In: S. Ranjan et al. (eds.), Nanoscience in Food and Agriculture 5, Sustainable Agriculture Reviews 26, DOI 10.1007/978-3-319-58496-6_10, Springer International Publishing AG

Sarlak N., A. Taherifar (2017) Encapsulation of Nanomaterials and Production of Nanofertilizers and Nanopesticides: Insecticides for Agri-food Production and Plant Disease Treatment. In: M. Ghorbanpour, K. Manika and A.Varma (Eds.) Nanoscience and Plant-Soil Systems. DOI: 10.1007/978-3-319-46835-8_18, pp: 481-498. Springer International Publishing AG

Selva Preetha P. (2011) Nano-fertilizer formulation to achieve balanced nutrition in green gram. $M S c$. (Ag.) Thesis, Tamil Nadu Agricultural University, Coimbatore, India

Shalaby T., Y. Bayoumi, T. Alshaal, N. Elhawat, A. Sztrik, H. El-Ramady (2017). Selenium fortification induces growth, antioxidant activity, yield and nutritional quality of lettuce in salt-affected soil using foliar and soil applications. Plant Soil, 421 (1-2): 245-258. https://doi.org/10.1007/s11104$017-3458-8$

Singh R.P., S. Kumar, M. Sainger, P.A. Sainger, D. Barnawal (2017) Eco-friendly Nitrogen Fertilizers for Sustainable Agriculture. In: A. Rakshit et al. (eds.), Adaptive Soil Management: From Theory to Practices, DOI 10.1007/978-981-10-3638-5_11, Springer Nature Singapore Pte Ltd.

Subramanian K.S., A. Manikandan, M. Thirunavukkarasu, C.S. Rahale (2015) Nanofertilizers for Balanced Crop Nutrition. In: M. Rai et al. (eds.), Nanotechnologies in Food and Agriculture, DOI 10.1007/978-3-319-14024-7_3, Springer International Publishing Switzerland

Subramanian K.S., M. Thirunavukkarasu (2017) Nanofertilizers and Nutrient Transformations in Soil. In: M. Ghorbanpour et al. (eds.), Nanoscience and Plant-Soil Systems, Soil Biology 48, DOI
10.1007/978-3-319-46835-8 11, International Publishing AG

Springer

Subramanian K.S., Sharmila Rahale C. (2013) Nanofertilizers - synthesis, characterization and application. In: Adhikari T, SubbaRao (eds.) Nanotechnology in Soil Science and Plant Nutrition. New India Publishing Agency, New Delhi, India.

Terekhova V., M. Gladkova, E. Milanovskiy and K. Kydralieva (2017) Engineered Nanomaterials' Effects on Soil Properties: Problems and Advances in Investigation. In: M. Ghorbanpour et al. (eds.), Nanoscience and Plant-Soil Systems, Soil Biology 48, DOI 10.1007/978-3-319-46835-8 4, Springer International Publishing AG

Wigger H. (2017) Environmental Release of and Exposure to Iron Oxide and Silver Nanoparticles: Prospective Estimations Based on Product Application Scenarios. Ph. D. Thesis, University of Bremen, Germany.DOI: 10.1007/978-3-65816791-2, Springer Fachmedien Wiesbaden GmbH, Springer Vieweg

Xu J., X. Luo, Y. Wang, Y. Feng (2018) Evaluation of zinc oxide nanoparticles on lettuce (Lactuca sativa L.) growth and soil bacterial community. Environmental Science and Pollution Research 25: 6026-6035. https://doi.org/10.1007/s11356-0170953-7

Yata V.K., B.C. Tiwari, I. Ahmad (2018) Nanoscience in food and agriculture: Research, industries and patents. Environ Chem.Lett. 16: 79-84. https://doi. org/10.1007/s10311-017-0666-7

Younis S.A., E.M. El-Fawal, P. Serp (2018) Nanowastes and the Environment: Potential Challenges and Opportunities of Nano-waste Management Paradigm for Greener Nanotechnologies. In: C. M. Hussain (ed.), Handbook of Environmental Materials Management. https://doi. org/10.1007/978-3-319-58538-3_53-1, Springer International Publishing AG

(Received 21/12/2018; accepted 12/2/2019) 